\title{
Generation Y Women's Cosmetic Decision: Insights from Brand Loyalty
}

\author{
Mohd Isham Abidin ${ }^{1}$, Rohaiza Kamis ${ }^{2}$, Shafinar Ismail ${ }^{3}$, Mohd Halim Mahphoth ${ }^{4}$, Mohd \\ Amirul Atan 5 \\ \{ishamabidin@uitm.edu.my $\left.{ }^{1}\right\}$ \\ Universiti Teknologi MARA, Malaysia' ${ }^{1,2,3,4,5}$
}

\begin{abstract}
With the expanding trend in the cosmetic industry, today's consumers are overflowed with various brands of beauty care products. In such circumstance, it may be an exorbitant undertaking for cosmetic companies to guarantee brand loyalty among the existing customers [1]. Therefore, it has become a vital need for companies to have a more noteworthy information on the determinants of brand loyalty of a specific brand of cosmetic. The purpose of this study is to investigate the factors that influence cosmetic brand loyalty among Generation $\mathrm{Y}$ women. A stratified random sampling was adopted in distributing questionnaires to 250 respondents. The data were analyzed using SPSS 18.0 which involved scale reliability, descriptive and multiple regression analyses. This study revealed that four key independent variables which are promotion, brand name, price and product quality had positive significant effects towards cosmetic brand loyalty among Generation $\mathrm{Y}$ women. Based on the results, some recommendations are suggested for future direction.
\end{abstract}

Keywords: Generation Y, Brand Loyalty, Promotion, Brand Name, Price, Product Quality

\section{Introduction}

Cosmetic products have become a necessity among Generation Y, especially among young and adult women, whereby it is also a typical and mainstream category of necessities that recognizes them with a more loosened up way of life, more noteworthy adaptability, and comfort [2]. Due to increasing numbers of consumers in the world, many businesses that are related to cosmetic products have grown rapidly. This reason acts as their needs in consumers' daily basis. Meanwhile, with the increasing number of competitions in the cosmetic industry, consumers are repeatedly flooded with information on different brands of the same product category of cosmetics. In such circumstance, it could be useful undertaking for a company to guarantee brand loyalty among existing customers. As an outcome, it has become an important step for marketers to have a more prominent information on the determinants of brand loyalty. Brand loyalty is one of the significant perspectives which is noteworthy for the management in sustaining its competitiveness in the market [3].

According to Alhedhaif et al. [4], the American Marketing Association defines brand loyalty as "the situation in which a consumer generally buys the same manufacturer-originated product or service repeatedly over time rather than buying from multiple suppliers within the category" or "the degree to which a consumer consistently purchases the same brand within a product class". It means customers will repeat purchasing the same product when the brand offers a high quality and convenient price. 
The individuals who were born during the '80s and the mid '90s are also called as the Generation Y, a name that is given based on the preceding generation which is the Generation $\mathrm{X}$. The Generation Y cohort is likewise alluded to as Millennials, the Internet generation, iGen and/or the Net generation. Also called the Echo Boomers, Generation Y are the offspring of Baby Boomers, or the individuals who were born during the time of expanded birth rates that happened somewhere between the years of 1946 and 1964. As indicated by Deal et al. [5], they are generally more educated than the previous generations, profoundly competent users of data and communication innovations (ICTs) and acclimated with the universe of social media applications and platforms. By and large, this cohort prefers to convey information through emails and instant messages instead of real face-to-face contact. In addition, learning for them is something beyond customary physical lecture rooms and physical seminars whereby they are mostly exposed to oral presentations by means of online courses, webinars, and online classes. Since the youngsters of this era have consistently had steady access to present day's innovation, for example, laptops, tablets, and smartphones since their childhood, their employment and public activity are continually characterized by or required to join the latest updates of such kinds of advancements.

There are numerous variables that impact brand loyalty, for example, brand name, product quality, price, features or design, store environment, promotion, and service quality [6]. These factors determine consumers' decision to purchase a superior item and appropriate for their countenances and body. Keeping loyal customers is important for firm performance and it relies upon on how the products of the company can attract customers and at the same time will increase the company's profit too. Promotion is important to attract customers buying the products and to gain trust from customers regardless of the products' prices. Promotion is a significant component which is a sort of communication with customers regarding item contributions and it is an approach to support purchase or sales of an item or service [7]. Promotion incorporates the utilization of advertising, personal selling, direct marketing, public relations, and sales promotion. Advertising through mass media platforms such as television and radio is one of the effective ways to approach customers. It can help to encourage positive perceptions in the customer's mind as well can help them differentiate the products [6]. Promotion through media is also suitable to encourage visual persons where they are easily affected through attractive advertising. According to De Chernatony [8], advertising is a useful instrument to create practical and emotional qualities of the brand and is utilized fundamentally by the organizations to accomplish sales by revealing the customers about the new or improved items. A brand name is a symbol for a product that makes the company's products differentiated from other competitors.

At the point when a brand name is carrying out its responsibility, it inspires positive pictures or feelings in buyers, which is the reason why branding can be so significant. According to Mansoor and Jalal [9], a global brand is defined as products that are produced globally and known in multiple countries while local brand means products that are produced domestically in a specific region. Brand name is significant for marketing specialists and clients, especially for the marketing specialists to utilize brand names in separating items from different contenders, taking the best situation in market to put their items and broadening the brand [3]. Furthermore, according to Hanzaee \& Andervazh [10], brand name does not only help identify the products but also acquires a rich set of symbols and meanings embodied by the products. These sets of symbols lead to customers' attraction to repeat purchasing the brand and reduce customers' switching behaviour. Customers tend to buy a familiar and well-known product or product that gives many benefits to them. 
Pricing determines what amount a customer is willing to pay in return for the product. Companies differ in their approach to this [11]. Price of the product is important to influence customers to buy the product. Customers are willing to pay at any price if the product gives a high quality and satisfies the customers' expectations. According to Alhedhaif et al. [4], price satisfaction has a direct impact on consumer behaviour and customer loyalty. By increasing loyalty among customers, it will prevent customers from switching to other brands thus will increase profit as well. As per Ong et al. [12], price is one of the aspects considered made by Malaysian customers to pick either local or imported items, where most Malaysians emphasise less on the price of products as they consistently see a superior benefit from high prices compared to lower ones. Basically, customers will seek for a high-quality product before they look at the price. It is because high quality products will give high impact towards the customers' experience. If the product does not have the expected quality, customers will switch to another brand. This implies the nature of a product might be characterized as its capacity to fulfil the consumer loyalty's and desires [4]. Product quality comprises of highlights and attributes of a product and service that bears on its capacity to fulfil expressed or inferred needs.

Materials used in a product is essential because it will affect to hand feel, texture and other performance aspects of the products. As for cosmetic products, the materials should not harm the consumers because the main reason to use cosmetic is for long shelf life and natural ingredients are needed in every cosmetic so that it does not harm consumers' health. Product quality is a main concern in firms' internationalization. They characterize product quality as a key trait that clients use to assess the products [10]. Product quality is generally a perceptual build as there are plenty of factors that impact a product's performance, toughness, fitness and other related matters. Besides, if the product can satisfy customer needs and wants, it is considered as high quality of product and gives high satisfaction to the consumers.

\section{Research Objectives}

a. To determine the relationship between promotion and brand loyalty among generation Y women.

b. To examine the relationship between brand name and brand loyalty among generation Y women.

c. To analyse the relationship between price and brand loyalty among generation $\mathrm{Y}$ women.

d. To identify the relationship between product quality and brand loyalty generation $\mathrm{Y}$ women.

e. To investigate the most factor that influencing brand loyalty towards cosmetic products among generation $\mathrm{Y}$ women.

\section{Research Questions}

a. Is there any relationship between promotion and brand loyalty among generation $\mathrm{Y}$ women?

b. Is there any relationship between brand name and brand loyalty among generation $\mathrm{Y}$ women?

c. Is there any relationship between price and brand loyalty among generation Y women? 
d. Is there any relationship between product quality and brand loyalty generation $\mathrm{Y}$ women?

e. What is the most factor that influences brand loyalty towards cosmetic products among generation Y women?

\section{Theoretical Framework}

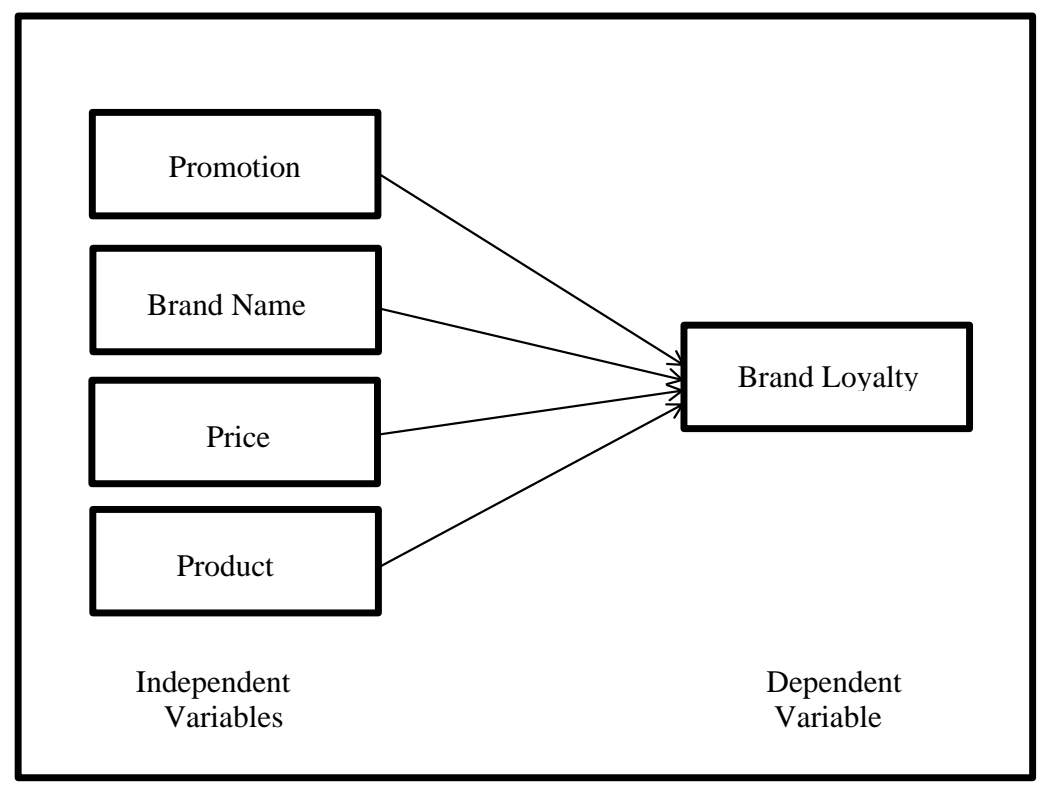

Source: Factors that affect consumers' brand loyalty towards cosmetic products [3].

\section{Hypotheses}

a. Hypothesis 1

H0: There is no relationship between promotion and brand loyalty among generation $\mathrm{Y}$ women.

$\mathrm{H} 1$ : There is a relationship between promotion and brand loyalty among generation $\mathrm{Y}$ women.

b. Hypothesis 2

H0: There is no relationship between brand name and brand loyalty among generation Y women.

H1: There is a relationship between brand name and brand loyalty among generation $\mathrm{Y}$ women.

c. Hypothesis 3

H0: There is no relationship between price and brand loyalty among generation $\mathrm{Y}$ women. 
H1: There is a relationship between price and brand loyalty among generation $\mathrm{Y}$ women.

d. Hypothesis 4

H0: There is no relationship between product quality and brand loyalty among generation $\mathrm{Y}$ women.

H1: There is a relationship between product quality and brand loyalty among generation $\mathrm{Y}$ women.

\section{Methodology}

The purpose of this study is to ascertain the factors affecting brand loyalty among Generation Y women. The respondents were Malaysian women in the state of Malacca aged between 26 to 39 years old. A stratified random sampling was used for this study. 250 sets of questionnaires were distributed to 250 respondents but only 212 sets were returned. All instruments were adapted from past research. In the questionnaire, brand loyalty consisted 4 items, promotion items consisted 4 items, brand name questions consisted 4 items, pricing questions consisted 4 items and product quality items consisted 4 questions. All variables used 5 Likert scale point from one (1) strongly disagree to five (5) strongly agree. SPSS 18.0 was utilized to record the data. Content validity was evaluated utilizing the reliability test, Cronbach alpha, while the theories were evaluated utilizing the regression analysis.

\section{Findings}

\subsection{Frequency Statistics}

A total of 212 respondents accommodated by returning the questionnaires that developed in $85 \%$ rate of return. As shown in Table 1, based on the demographic information, the sample was varied in several features. Approximately, 56.6\% (120) of the samples were Malay, followed by Chinese $20.3 \%$ (43), Indian were $16.5 \%$ (35) and 6.6\% (14) were others. For marital status, $32.1 \%$ (68) were single, $67 \%$ (142) were married, meanwhile $0.9 \%$ (2) were divorce. A majority of the respondents (107) aged between $31-35$ years old (50.5\%), followed by 56 respondents aged between $26-29$ years old (26.4) and (49) respondents aged between $36-39$ years old (23.1\%). The table also shows that $61.8 \%$ (131) of them earned RM2,501-RM3,500 per month, followed by $25.5 \%$ (54) earned RM1,501-RM2,500 per month, $8.5 \%$ (18) of the samples earned more than RM3,501 per month, followed by 4.2\% (9) earned below RM1,500 monthly. The highest number of monthly expenditures is RM201 - RM300 with 50.4\% (107) from the total respondents while the monthly expenditure between RM101 - RM200 scored the second highest by $30.1 \%$ with 65 respondents. It is followed by RM100 monthly expenditure by $11.8 \%$ (25) respondents. The lowest monthly expenditure is above RM301 with $7.7 \%$ (15) respondents. On the other hand, 57.5\% (122) of the respondents worked in the government sector followed by $39.2 \%$ (83) worked in private sector and only (3.3\%) 7 respondents were in other sectors such as self-employed and worked at other sectors than public, private, selfemployed. The most preferable cosmetic products are Others by $29.2 \%$ (62) respondents. The second preferred brand is Maybelline and followed by Silky Girl with $20.3 \%$ (43) and $17.9 \%$ ((38) respondents respectively. Next is Sephora with $14.6 \%$ (31) respondents. Other than that, 
Catrice, SimplySiti and Avon which were 5.2\% (11), 4.2\% (9) and $3.3 \%$ (7) respectively. Meanwhile, Qu Puteh has 2.4\% (5) and D'Herbs and D'Nars shared the same result of 1.4\% (3).

Table 1. Sample's Characteristics

\begin{tabular}{|c|c|c|c|}
\hline $\begin{array}{c}\text { Respondent's } \\
\text { Profile }\end{array}$ & Response Set & Frequency & Percentage (\%) \\
\hline \multirow{4}{*}{ Race } & Malay & 120 & 56.6 \\
\hline & Chinese & 43 & 20.3 \\
\hline & Indian & 35 & 16.5 \\
\hline & Others & 14 & 6.6 \\
\hline \multirow{3}{*}{ Marital Status } & Single & 68 & 32.1 \\
\hline & Married & 142 & 67.0 \\
\hline & Divorce & 2 & 0.9 \\
\hline \multirow{3}{*}{ Age } & $26-29$ Years Old & 56 & 26.4 \\
\hline & $31-35$ Years Old & 107 & 50.5 \\
\hline & 36-39 Years Old & 49 & 23.1 \\
\hline \multirow{4}{*}{ Income Per Month } & & 9 & \\
\hline & $\begin{array}{l}\text { Below RM1,500 } \\
\text { RM1,501-RM2,500 }\end{array}$ & 54 & $\begin{array}{c}4.2 \\
25.5\end{array}$ \\
\hline & RM2,501-RM3,500 & 131 & 61.8 \\
\hline & Above RM3,501 & & 8.5 \\
\hline \multirow{4}{*}{ Monthly Expenditure } & Below RM100 & 25 & 11.8 \\
\hline & RM101-RM200 & 65 & 30.1 \\
\hline & RM201-RM300 & 107 & 50.4 \\
\hline & Above RM301 & 15 & 7.7 \\
\hline \multirow{3}{*}{ Working Sector } & Government & 122 & 57.5 \\
\hline & Private & 83 & 39.2 \\
\hline & Others & 7 & 3.3 \\
\hline \multirow{10}{*}{$\begin{array}{l}\text { Most Preferable } \\
\text { Cosmetic } \\
\text { Products }\end{array}$} & Silky Girl & 38 & 17.9 \\
\hline & Catrice & 11 & 5.2 \\
\hline & Maybelline & 43 & 20.3 \\
\hline & Sephora & 31 & 14.6 \\
\hline & Avon & 7 & 3.3 \\
\hline & SimplySiti & 9 & 4.2 \\
\hline & D'herbs & 3 & 1.4 \\
\hline & Qu Puteh & 5 & 2.4 \\
\hline & D'nars & 3 & 1.4 \\
\hline & Others & 62 & 29.2 \\
\hline
\end{tabular}

\subsection{Descriptive Analysis}

Table 2. Descriptive Result

\begin{tabular}{lcc}
\hline \multicolumn{1}{c}{ Variables } & Mean & Std. Deviation \\
\hline Promotion & 3.9811 & 0.59090 \\
Brand Name & 4.1309 & 0.61836 \\
Price & 3.9104 & 0.70643 \\
Product Quality & 4.0271 & 0.60764 \\
\hline
\end{tabular}


Table 2 shows the average means and standard deviations for each variable in this research. The highest mean score is obtained by brand name with 4.1309 . The second highest is product quality with total average of mean 4.0271 and followed by promotion with 3.9811 . The lowest average mean is price with 3.9104 . The consumers will have a high degree of loyalty towards a specific brand if they pay more for the brand name.

\subsection{Reliability Analysis}

The Cronbach's Alpha for brand loyalty is 0.878 , promotion is 0.826 , brand name is 0.845 , price is 0.830 and product quality is 0.823 where all are considered as high reliability. The reliability of the measure indicates the stability of the instrument used. It can be concluded that Cronbach's Alpha values for all variables have a good strength of association as the values are more than 0.8 , therefore, all the variables used in this study were reliable.

Table 3. Reliability Result

\begin{tabular}{lccc}
\hline \multicolumn{1}{c}{ Factors } & No. of Items & Cronbach's Alpha & Strength \\
\hline Brand Loyalty & 4 & 0.878 & GOOD \\
Promotion & 4 & 0.826 & GOOD \\
Brand Name & 4 & 0.845 & GOOD \\
Price & 4 & 0.830 & GOOD \\
Product Quality & 4 & 0.823 & GOOD \\
\hline
\end{tabular}

\subsection{Pearson's Correlation Analysis}

Table 4. Pearson's Correlation Result

\begin{tabular}{lcc}
\hline \multicolumn{1}{c}{ Variables } & R & Strength of Association \\
\hline Brand Loyalty and Promotion & 0.417 & Moderate \\
Brand Loyalty and Brand Name & 0.560 & Strong \\
Brand Loyalty and Price & 0.580 & Strong \\
Brand Loyalty and Product & 0.634 & Strong \\
Quality & & \\
\hline
\end{tabular}

The first correlation is to identify the association between brand loyalty and promotion and the result shows that the correlation is $\mathrm{r}=0.417, \mathrm{p}=0.000$. Therefore, there is a moderate relationship between brand loyalty and promotion. Next, correlation is used to examine the association between brand loyalty and brand name. The result indicated that the correlation is $\mathrm{r}=0.560, \mathrm{p}=0.000$. Therefore, there is a strong relationship between brand loyalty and brand name. The third correlation is to determine the association between brand loyalty and price. The result shows that the correlation is $\mathrm{r}=0.580, \mathrm{p}=0.000$. Therefore, there is a strong relationship between brand loyalty and price. The last correlation is to examine the association between brand loyalty and product quality and the result demonstrates that the correlation is $\mathrm{r}=0.634, \mathrm{p}=0.000$. Hence, there is a strong relationship between brand loyalty and product quality. 


\subsection{Multiple Regression Analysis}

\begin{tabular}{lccc}
\multicolumn{4}{c}{ Table 5. Multiple Regression Result } \\
\hline \multicolumn{1}{c}{ Independent Variables } & $\begin{array}{c}\text { Standardized } \\
\text { Coefficient (Beta) }\end{array}$ & t-Values & $\begin{array}{c}\text { Significant } \\
\text { Value }\end{array}$ \\
\hline Promotion & .061 & 1.009 & .314 \\
Brand Name & .274 & 4.365 & .000 \\
Price & .292 & 4.551 & .000 \\
Product Quality & .238 & 3.048 & .003 \\
\hline
\end{tabular}

Table 5 demonstrates the regression results. Based on the results, promotion variable shows no significance relationship with brand loyalty $(\mathrm{t}=1.009, \mathrm{p}=0.314)$. Hence, $\mathrm{H}_{1}$ is rejected. Brand name variable is significantly associated with brand loyalty $(\mathrm{t}=4.365, \mathrm{p}=0.000)$. Hence, $\mathrm{H}_{2}$ is supported. Price variable is shown to have a significant relationship with brand loyalty $(\mathrm{t}=4.551, \mathrm{p}=0.000)$. Hence, $\mathrm{H}_{3}$ is also supported. Lastly, for Product Quality variable, it is significantly associated with brand loyalty $(\mathrm{t}=3.048, \mathrm{p}=0.003)$. Hence $\mathrm{H}_{4}$ is also supported.

\section{Conclusion and Discussion}

The results showed that all the four variables which are promotion, brand name price and product quality were positively correlated with the dependent variable (brand loyalty). Meanwhile, using the Regression analysis, only one independent variable was not accepted which is promotion. The result demonstrates that all independent variables achieved and had a significant relationship. The analysis for brand name showed a strong association between brand name and brand loyalty where the result shows $r=0.560$. That implies buyers lean toward brand image when they see positive advantages or capacity from that item.

Furthermore, for product quality and brand loyalty variables, it also demonstrated a strong association by $r=0.634$. Compared to other variables, product quality variable has the strongest association with brand loyalty. The reason is because consumers are very concern about what they consume to prevent any infections on their skin or body. On the other hand, consumers prefer to buy international products rather than local products. Therefore, product quality is very important to maintain consumer loyalty. Price also has a strong association with brand loyalty by $r=0.580$. Findings from this study are also coherent with other several studies where price is considered as a sensitive matter in life where everyone tries to purchase the best products with high quality and affordable price. They will buy products that satisfy their needs with appropriate prices. Lastly, for promotion and brand loyalty variables, the result showed that there is a moderate association of $r=0.417$. It also means that promotion variable was not considered an important aspect of brand loyalty.

The study has its own limitations. Firstly, the sample size might be too small whereby only 250 respondents participated. Moreover, the used of online survey might have its own shortcomings such as respondents tend to answer the questions more than once. Furthermore, lack of cooperation and limitations of the source are also identified as other limitations for the study.

\section{References}

[1] M. Srivastava, "A study of determinants of brand loyalty in cosmetics for women consumers of 
Pune city using path analysis via regression," Indian J. Mark., vol. 46, no. 6, pp. 33-50, 2016.

[2] D. Azuizkulov, "Country of origin and brand loyalty on cosmetic products among Universiti Utara Malaysia students," Atl. Rev. Econ., vol. 2, 2013.

[3] K. Chaiyasit, "Marketing Implication Relating To Identified Factors That Influence Customer's Loyalty Towards L'Oreal Cosmetics at Siam Paragon Mall in Bangkok," 2019.

[4] S. Alhedhaif, U. Lele, and B. A. Kaifi, "Brand loyalty and factors affecting cosmetics buying behavior of saudi female consumers," J. Bus. Stud. Q., vol. 7, no. 3, p. 24, 2016.

[5] J. J. Deal, D. G. Altman, and S. G. Rogelberg, "Millennials at work: What we know and what we need to do (if anything)," J. Bus. Psychol., vol. 25, no. 2, pp. 191-199, 2010.

[6] H. S. Khraim, "The influence of brand loyalty on cosmetics buying behavior of UAE female consumers," Int. J. Mark. Stud., vol. 3, no. 2, p. 123, 2011.

[7] C.-T. Chiang and W.-C. Yu, "Research of female consumer behavior in cosmetics market case study of female consumers in Hsinchu Area Taiwan," I-Business, vol. 2, no. 4, p. 348, 2010.

[8] L. De Chernatony, From brand vision to brand evaluation: The strategic process of growing and strengthening brands. Routledge, 2010.

[9] D. Mansoor and A. Jalal, "The global business crisis and consumer behavior: Kingdom of Bahrain as a case study," Int. J. Bus. Manag., vol. 6, no. 1, p. 104, 2011.

[10] K. H. Hanzaee and L. Andervazh, "The influence of brand loyalty on cosmetics purchase intention of Iranian female consumers," J. Basic Appl. Sci. Res., vol. 2, no. 5, pp. 5389-5398, 2012.

[11] A. Hinterhuber and S. Liozu, "Is it time to rethink your pricing strategy," MIT Sloan Manag. Rev., vol. 53, no. 4, pp. 69-77, 2012.

[12] C. H. Ong, H. W. Lee, and T. Ramayah, "Impact of brand experience on loyalty," J. Hosp. Mark. Manag., vol. 27, no. 7, pp. 755-774, 2018. 